\title{
THE BIRDS OF GUADELOUPE AND ADJACENT ISLANDS
}

\author{
By STUART T. DANFORTH, \\ College of Agriculture and Mechanic Arts, University of Puerto Rico, \\ Mayagïez, Puerto Rico.
}

\section{GUAdeLOUPe}

Guadeloupe is the largest of the islands of the Lesser Antilles, having an area of about 583 square miles. It is situated in approximately $16^{\circ}$ North latitude and $64^{\circ}$ West longitude.

The Island in reality consists of two distinct islands, Guadeloupe proper (containing about 364 square miles) and Grande Terre (containing about 219 square miles) separated from each other by a shallow arm of the sea from 90 to 300 feet wide known as "La Rivière Salée", which is traversed by a highway bridge near Pointeá-Pitre. The two islands are of very different formation and appearance. Guadeloupe proper is of volcanic formation, consisting mainly of a vast central mountain mass covered with virgin rain forest, much of which remains unexplored. The highest peak, known as the Soufrière, attains an elevation of 4,868 feet, and has a crater from which sulphur is obtained, and old lava flows may be observed near the crater. Although still feebly active, it has not erupted violently within historical times. The rain forest does not extend much above 4,000 feet, as the regions above that altitude are so windswept that only a very low type can exist, and practically no birds may be observed there. The rain forest extends down to about 2,000 feet elevation (or somewhat lower in some places). Below that is found second growth country, or, in the North and East of the Island, a beautiful rather low type of hardwood forest extending down to where cultivations begin, and reaching practically to sea level in some regions, as at Sainte Marie and Sainte Rose. The ever-increasing banana plantations are constantly encroaching upon this zone. Below this are the lowland savannas, largely planted to cane, at least in the South and East. On the West coast the corresponding area is somewhat less level and more barren, being covered mainly with a semi-xerophytic type of scrub where all except a very few species of birds are very scarce. Except for a small voleanic lake in the mountains, I know of no ponds in Guadeloupe 
proper. There are a few mangrove swamps in the northeastern corner.

Grande Terre is of coral limestone formation, with only low hill formations, making a monotonous low, level, and dusty landscape. There are a few limestone sinkholes containing water where a few aquatic birds may be found, and some rather extensive mangrove swamps along the coast, particularly in the western part of the Island near Port-Louis and Vieux-Bour's.

Due to the writings of early travellers, there are some records of Guadeloupe bird life extending back to a very early date. For example, there is a record of an extinct macaw stated by Navaret to have been seen on Columbus' voyage of discovery. Huttich (1534), Dutertre (1674) and Père Labat (1742) have left records (in some cases very extensive) of their observations of Guadeloupe birds, and our only knowledge of various species now extinct is due to them.

Next in order of time comes the eminent resident naturalist, Dr. F. L. L'Herminier, who formed very extensive collections of birds from 1827 to 1844, and contemplated publishing a work on the ornithology of the Island. Unfortunately all his specimens and notes were destroyed in the great Pointe-á-Pitre fire of 1844, so that all we have left of his work are a few specimens (including the types of several species) he had sent to foreign ornithologists, and a nominal manuscript list, apparently written from memory after the fire, of 135 species he believed he had found in Guadeloupe. This list by indirect means got into Lawrence's hands, and he unfortunately published it verbatim (Proc. U.S.N.M., I, 1879, pp. 450-451). I say unfortunately, since Dr. L'Herminier's memory evidently failed him, resulting in the occurrence in this list of a highly improbable and chaotic assemblage of European, North American and South American birds, in addition to those known to occur only in other West Indian islands, and nomina nuda. On this account, most authors have completely disregarded the list when treating of the birds of the Island, while others have picked birds to list here and there according to their fancy, with no apparent rational basis for their choices, thereby greatly complicating the literature of the avifauna of Guadeloupe, and creating difficulties for future workers. It seems only reasonable that since all birds are treated alike in this list, one must adopt a consistent method, and either accept all or accept none of the birds in the list. The former course is clearly absurd, due to the many obviously highly improbable if 
not impossible records, so I have decided upon the course of accepting no records from the list, and listing only birds of which there is some specimen from Guadeloupe extant, or a more or less definite record which does not obviously originate exclusively from this list. Therefore let the reader be not surprised at finding omitted from the annotated list eertain species which have been listed by Bond, Ridgway, Bent, and other modern authors, which on being checked up apparently had no other basis of authority than L'Herminier's list.

Shortly after the Pointe-á-Pitre fire the Musèe L'Herminier was built, but it suffered serious damage in the hurricane of 1928, and had to be installed in new quarters afterwards. Much of the library was destroyed, but the birds were saved. In a large central glasscovered case there are a large number of birds said to be all from Guadeloupe, but otherwise completely without data, and I could not even ascertain who had obtained and prepared the specimens. However, they are of some antiquity, judging by their appearance, and by the fact that such species as the burrowing owl and clapper rail, which no longer exist in this region, are to be seen there.

Fred A. Ober, collecting for the Smithsonian Institution, worked in Guadeloupe in August and September 1878, leaving in October, and forwarded 132 specimens of birds. An annotated list of 45 species collected or recorded by him was published by Lawrence (Proc. U.S.N.M., I, Apr. 22, 1879, pp. 449-462).

There are in the U. S. National Museum a rather large number of old skins obtained in Guadeloupe by L. Guesde. These are all without further data, but they seem to be of comparable age to those in the Musée L'Herminier, and I am impelled to wonder if it might not have been the same person who prepared both. They were certainly obtained before 1885, as there is published mention of some. of them dating back to that year.

Dr. St. Felix Colardeau, of Basse-terre, sent a number of specimens and notes to Lawrence during the period from 1882 to 1890, including the types of his Chaetura dominicana colardeaui and Ceryle stictipennis. Lawrence published an account of 10 species received from Dr. Colardeau, together with notes on their habits also received from him, in the Proc. of the U.S.N.M., 8, 1885, pp. 621-625.

W. B. Richardson, working for Cory, collected 76 specimens representing 15 species on Grande Terre in February, 1886. Cory pub- 
lished a report on this collection in the Ibis for October, 1886, pp. 471-475.

C. S. Winch, also collecting for Cory, spent some time in August, September and October, 1890, working in Guadeloupe. He obtained a rather large number of specimens, representing 42 species, a nominal list of which was published in the Auk for January 1891 (pp. $47-49)$.

In 1894 Jules Ballet publishes a work entitled "La Guadeloupe. Renseignements sur L'Histoire, La Flore, La Faune, La Géologie, La Mineralogie, L'Agriculture, Le Commerce, L'Industrie, La Législation, L'Administration" in 3 volumes (Basse-Terre). The section on birds occupies pages 7-39 of the second volume; but little original information is offered.

In 1914 G. K. Noble, representing the Museum of Comparative Zoölogy, spent the period from June 22 to September 12 working on Guadeloupe. Later he published a rather extensive report on the resident birds of the island (Bulletin of the Mus. of Comp. Zoöl., 60, 1916, pp. 359-396), in which 46 resident species are discussed.

James Bond, representing the Academy of Natural Sciences of Philadelphia, spent a short time collecting in Guadeloupe early in 1930. He has published no complete report of his work in Guadeloupe although observations on the birds of the Island may be found in his "Birds of the West Indies" (1936).

M. Mimi published a chapter on the fauna of the island in "La Guadeloupe du Tricentenaire" (Basse-Terre, 1935). It is a good source for local names; but has only slight original information.

The present author made several short in transit visits to Guadeloupe, on which opportunity was always taken to observe birds, as on December 29, 1930 and June 18, 1931, but his real work there was done in 1937, with Virgilio Biaggi, Jr. as assistant, when the period from June 10 to July 26 was spent there, with the exception of a few days used for visiting neighboring islets. We had intended to spend a somewhat longer period in this region, working on Guadeloupe proper, and spending a week instead of the short time actually spent on Marie Galante, and making a trip to Petite Terre (to say nothing of spending two weeks or so in Martinique), when we were suddenly summoned back to Puerto Rico much in advance of the time we had planned on returning. To make matters even worse we had to leave earlier than would have otherwise been necessary on account of transportation facilities. During our stay we made observations upon 38 species of birds in Guadeloupe, includ- 
ing Grande Terre. These were mostly breeding birds, as we were not in the season for many migrants. We collected 133 specimens representing 24 species there.

\section{Les SaINTes}

Lying from six to eight miles directly south of Guadeloupe proper is a group of six small islands of volcanic formation known as Les Iles des Saintes. The two largest are Terre-de-Bas and Terre-de Haut; the other four are much smaller, and include Grand Ilet and Ilet á Cabrits. The total area of the entire group is only about $5 \frac{1}{2}$ square miles. By far the most interesting of the group is Terrede-Bas, the most westerly of the islets. It is mostly hilly, the highest peak reaching an elevation of 932 feet. Part of the lowlands are cultivated, but the hills are covered with brush, and the higher parts support quite a luxuriant type of dry forest. The only water noted upon the Island consisted of a few stock-watering pools in which pond-lilies grew.

Terre-de-Haut has become a popular weekend and summer vacation resort for the more well-to-do people of Guadeloupe, but it is much less interesting than Terre-de-Bas from the naturalist's point of view. A large part of the Island consists of low pasture. The hills are in part covered with dry scrub, but there is no such luxuriant forest as on Terre-de-Bas. The highest peak (1,036 feet) is rocky and almost bare.

Noble obtained a few specimens from Les Saintes in September, 1914 , but these were probably brought to him, as he makes no statement of having visited the islands, and includes many hearsay reports of birds occurring here gathered from fishermen.

Bonds writes me that he has visited the islands, and some birds records from here are included in his "Birds of the West Indies" (1936). His visit was presumably after 1930, as in that year he states (Proc. Acad. Nat. Sci, Phila., 82, 1930, p. 337) that the birds of Les Saintes "are at present completely unknown".

We visited Les Saintes on July 5, 1937, leaving Trois Rivières (on the mainland of Guadeloupe) very early in the morning in a sailing vessel with auxiliary motor which we had chartered for the day. We spent most of the morning on Terre-de-bas, and the afternoon on Terre-de-Haut (passing close to Grand Ilet on the way), returning to Trois Rivières in the evening. We observed 19 species of birds, and collected 15 specimens representing 10 species. 


\section{DÉSIRADE}

Désirade is a long, narrow island of limestone formation situated about six miles east and slightly north of Pointe des Châteaux, the extreme eastern tip of Grande Terre. The sea in this region is so rough and the wind so contrary, and the landing so precarious, that the voyage is locally considered as very dangerous, and requires about 12 hours in small sailing vessels, which are the only regular means of transportation.

The Island consists mainly of a long, narrow, precipitously-walled plateau about 7 miles in length, and seldom much over a mile and a half in width. In most places there are some narrow strips of low, flat land intervening between the walls of the plateau and the sea, and near the town (Grande Anse) there is a small pond, which was practically dry at the time of our visit. The trail from the town to the plateau goes up the only available ravine, in parts of which there is considerable growth of xerophytic trees and bushes in which Margarops abounds. The top of the plateau is very level, and grown to tall brush, so that on the narrow path which traverses most of the length of it one can see but a short distance in any direction, and the heat is most oppressive due to the fact that one is so enclosed by the dense brush. The bare limestone protrudes through the earth so much that one treads it as much as the earth. The plateau reminded me much of that of Mona Island, but differed in its long, narrow shape, much greater elevation, and somewhat smaller proportion of protruding rock. Birds were decidedly scarce upon the plateau.

The first ornithologist to visit Désirade was W. B. Richardson, working for Cory, who collected there in March, 1886. The exact dates of his visit are not recorded, but in my notes I have annotations on specimens in the Field Museum collected from March 7 to 13, 1886. He collected 57 specimens representing 11 species, which were reported upon by Cory in the Ibis for October, 1886, pp. 471-475.

The second ornithologist known to have visited Désirade is Bond, who made a short visit during the latter part of January, 1930. He made some slight mention of Désirade birds in the Proc. Acad. Nat. Sci. Phila., 82, 1930, pp. 330 and 337, and other references to the birds of the Island are made in his "Birds of the West Indies".

Our visit to Désirade was made on July 9, 1937, when, thanks to the great kindness of the Governor of Guadeloupe, a eustoms patroI launch was placed at our service for the trip. With its powerfuI twin motors an ordinarily tedious and extremely uncomfortable trip 
was made in rapid time with a minimum of discomfort. We left Pointe-á-Pitre at about 3 A.M., and arrived at Désirade by 8 A.M. The return trip was started at 5:30 P. M., and Pointe-á-Pitre was reached soon after 10 P.M. Charles Romney, a student of the University of Puerto Rico who was visiting relatives in Guadeloupe, accompanied us on this trip and devoted his time to collecting insects. During the day we made observations upon 15 species of birds, and brought back 13 specimens representing 9 species of birds, undoubtedly a smaller catch than we would have made if one of our guns had not most unfortunately broken down very early in the day.

\section{Marie Galante}

Marie Galante, the largest and most populous of the dependencies of Guadeloupe, is a roughly circular limestone island situated about 15 miles south of Grande Terre. It has an area of about 55 square miles, and possesses three towns (Grand-Bourg, Saint-Louis, and Capesterre). The main part of the Island consists of a plateau-like elevation (the highest point of which is 625 feet above sea level), but more rolling and less level than the plateauss of many limestone islands. Near the west coast there is some low marshy country of considerable extent, Ruounas Trois Islets where lowland birds abound. On the climb up the plateau one finds a few mango and other trees approximating woodland, but nothing that could be called a real forest. Trees are very scarce on top of the wind-swept plateau.

Burrowing owls were obtained from Marie Galante many years ago, the records do not show by whom. Possibly other $\cdot$ older specimens, supposedly from Guadeloupe, are actually from here.

W. B. Richardson, collecting for Cory, visited Marie Galante in February and March, 1886. He obtained 67 specimens representing 13 species, which were reported upon by Cory (Ibis, 1886, pp. 471$475)$.

Bond writes me that he has visited the Island, but he has published no report of his visit.

We had intended spending a week on Marie Galante, but due to our unexpectedly early recall to Puerto Rico, this unfortunately had to be reduced to less than two days. But fortune was not all against us, as due to our obtaining the cooperation of M. Marcel Balastide, a resident sportsman with a car, and a thorough knowledge of the country and its birds, we were enabled to visit a large proportion of the best bird country in the limited time available.

We went to Marie Galante on July 17, 1937, on the weekly trip 
of the mail sloop equipped with auxiliary motor "Père Labat", which makes the trip from Pointe-á-Pitre to Grand Bourg in slightly over four hours, and returned in the same vessel the following afternoon, embarking from Saint-Louis to save an hour of precious time on the Island. Charles Romney accompanied us and collected insects. We made observations upon 18 species of birds, and obtained 17 specimens representing 14 species.

\section{ACKNOWLEDGMENTS}

To His Excellency, the Governor of Guadeloupe, M. Mené, we are greatly indebted for permission to collect in the closed season (something very difficult of attainment in this Island), and also for graciously facilitating us with the means of visiting Désirade.

A very special debt of gratitude is owed to M. Gilbert Chatelain, Chief of the Service des Eaux et Forêts, without whose truly friendly and cordial interest our work in these islands would have been a failure. It was due to his intercessions on our behalf that all government cooperation with our work was obtained, and in addition he assisted us personally in many ways, and a personal friendship was developed which has continued after we left the Island.

M. Marcel Party, proprietor of the Hotel Dolé-les-Bains, assisted us in many ways. He is a sportsman, and on occasions accompanied us in the field, and on others provided us with transportation to likely collecting grounds.

To M. Marcel Balastide of Marie Galante we are indebted for the most efficient way he, after ascertaining the aims of our visit, personally managed our activities in that Island to make the most of a short visit.

\section{Notes on the Avifauna}

As will be seen by the following annotated list, 91 forms are known from the area covered by this paper. Only reasonably certain records are included, all records for which the only. basis is L'Herminier's list (see ante) being excluded. However, the evidence for some of the forms admitted to the list is not completely satisfactory, but since the evidence is given in each case, the reader may decide for himself how much value to place upon it. Also, since this list is confined to modern birds, records of the various extinct Psittaciformes which are not known from specimens are not included. 
Of the 91 forms known from the region, 88 are recorded from Guadeloupe. Of these, 2 are here recorded for the first time.

From Les Saintes 25 species have been recorded, some on rather doubtful evidence. Ten species are here recorded as new.

The Désirade list totals 20, of which 5 are here first recorded.

From Marie Galante 22 species are known, of which 7 are listed here for the first time.

\section{AnNotated List \\ Podilymbus podiceps antillarum Bangs \\ ANTILLEAN PIED-BILLED GREBE \\ Chien d'Eau}

Guadeloupe: Apparently very rare. Noble obtained an adult and two downy young at the Grand Etang, Cluny, in July 1914. On July 16, 1937 we observed an adult at a limestome sinkhole near Sainte Anne, Grande Terre.

\section{Puffinus Therminieri lherminieri Lesson \\ AUDUBON'S SHEARWATER}

Diablotin

Guadeloupe: Murphy (Oceanic Birds of South America, 1936, p. 684) mentions skins in the American Museum of Natural History taken in Guadeloupe in May.

\section{Pterodroma hasitata (Kuhl) \\ BLACK-CAPPED PETREL}

Diablotin

Guadeloupe: Formerly nested in the mountains, but not recorded for many years, and possibly extinct.

Phaëthon aethereus mesonauta Peters

$$
\text { RED-BILLED TROPIC BIRD }
$$

Paille-en-queue

Guadeloupe: Listed by various authors. It was reported to Noble as nesting at Tête Anglais, and Bond observed it was Guadeloupe. 
Les Saintes: Fishermen reported it to Noble as nesting. On July 5, 1937 we observed a number nesting on the cliffs at Terrede-Bas.

Désirade: The field Museum has a male obtained March 10, 1886 by Richardson.

$$
\begin{gathered}
\text { Sula leucogaster leucogaster (Boddaert) } \\
\text { ВОову }
\end{gathered}
$$

Fou Noir

Guadeloupe: Fishermen reported it to Noble as nesting at Tête Anglais.

Les Saintes: Reported to Noble as nesting.

Désirade: One seen off the coast July 9, 1937.

$$
\begin{gathered}
\text { Sula sula sula (Linnaeus) } \\
\text { RED-FоOTED BоOву } \\
\text { Fou Blanc }
\end{gathered}
$$

Guadeloupe: Fishermen reported it to Noble as nesting at Tête Anglais.

Les Saintes: Reported to Noble as nesting. It is doubtful if the species is still to be encountered in this region.

\section{Phalacrocorax auritus floridanus (Audubon) DOUBLE-CRESTED CORMORANT}

Guadeloupe: Rare straggler. There is an immature specimen in the British Museum obtained by Admiral A. H. Markham.

$$
\begin{gathered}
\text { Fregata magnificens rothschildi Mathews } \\
\text { MAN-O-WAR BIRD } \\
\text { Frégate }
\end{gathered}
$$

Guadeloupe: Fairly common along the coast; observed at Basseterre, Malendure, Bouillante, La Boucan, Port-Louis and VieuxBourg (Grande Terre) in 1937. Said to breed on Tête Anglais.

Les Saintes: One observed at Terre-de-Haut and one at Terre-de Bas on July 5, 1937. Not previously recorded. 
Ardea herodias adoxa Oberholser

WEST INDIAN GREAT'BLUE HERON

\section{Crabier Rada}

Guadeloupe: There are two specimens in juvenile plumage obtained by L. Gresde in the U. S. National Museum.

\section{Florida caerulea (Linnaeus)}

LITTLE BLUE HERON

\section{Crabier}

Guadeloupe: Although this as well as both the egrets have been recorded based on L'Herminier's list, the first positive record for the island is apparently that recorded by May T. Cooke (Bird-banding, 9, 1938, p. 81) of an individual banded at Glen Allan, Miss., on May 24, 1936, and killed at Saint-Francois, Grande Terre, on September 30,1936 . This raises the problem of whether or not the Little Blue Herons resident in the West Indies constitute a distinct race (caerulescens) supplemented by migratory individuals of the typical race from the continent or not. The material at hand is too scanty to determine this point.

An individual in pied transition plumage was observed at PortLouis, Grande Terre on July 8, 1937.

\section{Butorides virescens maculatus (Boddaert)}

WEST INDIAN GREEN HIERON

$$
\text { Quio }
$$

Guadeloupe: Common and well known. An adult male collected at Dolé on June 17, 1937 had eaten three fresh water shrimps, and the stomach of an immature male from Sainte Anne, Grande Terre, July 16, 1937 contained 6 adult dragonflies, Lepthemis vesiculosa. The adult male measured, length 462 ; wing 176.6 ; tail 54.5 ; exposed culmen 58.4, and tarsus 47 millimeters.

Les Saintes: Noble obtained 6 specimens the first week in September, 1914. On July 5, 1937 we observed single individuals at stock watering ponds on both Terre-de-Bas and Terre-de-Haut.

Désirade: One observed at the nearly dry pond on July 9, 1937. Richardson obtained the species in 1886.

Marie Galante: An adult male from Saint-Louis, July 18, 1937 
constitutes the first record for the island. It measures, length 450; wing 166 ; tail 56.4 ; exposed culmen 62.1 ; tarsus 45 millimeters. Its stomach contained a damselfly, a crayfish, 2 small weevile ( $T y l o-$ derma. sp.), and some miscellaneous insect fragments.

\section{Nyctanassa violacea (Linnaeus)}

YELLOW-CROWNED NIGHT HERON

Crabier

Guadeloupe: Obtained by Ober, and Noble records it as breeding east of Sainte Rose.

\section{Phoenicopterus ruber Linnaeus \\ FLAMINGO \\ Flamant}

Guadeloupe: Clark (Auk, 1905, p. 318) records the flamingo as occurring formerly south to Guadeloupe.

\section{Dendrocygna autumnatis discolor Sclater and Salvin}

GRAY-breasted TREE DUCK

Guadeloupe: Noble believes he saw one July 22, 1914 on a pond near Cluny.

\section{Dafila bahamensis bahamensis (Linnaeus) \\ GRAY-BREASTED TREE DUCK \\ Canard Tête-blanche}

Guadeloupe: Listed by Lawrence. Mimi (Guad. du Tricentenaire, 1935, p. 137) also mentions it.

Nyroca affinis (Eyton)

LESSER SCAUP DUCK

Canard Sauvage

Guadeloupe: There are no published records, but an unlabelled mounted female is exhibited in a case of birds all of which are supposed to be from Guadeloupe in the Musée L'Herminier. Undoubt- 
edly this and various other migratory ducks, a number of which were listed by L'Herminier, occur oceasionally during the winter months.

Erismatura jamaicensis jamaicensis (Gmelin)

WEST INDIAN RUDDY DUCK

Guadeloupe: There is no published record, but in a case of mounted birds all supposed to be from Guadeloupe in the Musée $\mathrm{L}$ 'Herminier there are two unlabelled mounted females, and on July 16, 1937 at a limestone sinkhole near Sainte Anne, Grande Terre, we collected a female. It measured: culmen 42.5 ; breadth of bill at widest part 23.6 ; wing (are) 135 ; tarsus 32.8 , and tail 73.5 millimeters.

\section{Nomonyx dominicus (Linnaeus)}

\section{MASKED DUCK}

Guadeloupe: Although there is no published record other than that of L'Herminier, I am admitting the species to this list on the basis of a mounted specimen in a case of birds supposedly all from Guadeloupe in the Musée L'Herminier.

[Buteo platypterus subsp.

BROAD-WINGED HAWK

Guadeloupe: Of doubtful occurrence. Noble (Bull. M. C. Z., 60, 1916, p. 362) states that it has been seen by Pointe-á-Pitre sportsmen, and he considers it a straggler.]

[Buteogallus anthracinus cancrivorus (Clark).

\section{BLACK HAWK}

Guadeloupe: Listed here hypothetically on the basis of a statement by Noble (Bull. M. C. Z., 60, 1916, p. 362) that it has been observed by Pointe-á-Pitre sportsmen.]

Falco peregrinus anatum Bonaparte

DUCK HAWK

\section{Gligli Montagne}

Guadeloupe: I list this species with some hesitation, as all rec- 
ords except that of Mimi (Guadeloupe du Tricentenaire, 1935, p. 135) apparently originate from L'Herminier's list, and that is indefinite.

Falco columbarius columbarius Linnaeus

PIGEON HAWK

Gligli Montagne

Guadeloupe: What I have said of the Duck Hawk applies verbatim to this species also.

\section{Falco sparverius caribaearum Gmelin}

ANTILLEAN SPARROW HAWK

\section{Gligli}

Guadeloupe: Previous collectors have recorded it as common. In 1937 we found it only fairly common on Guadeloupe proper, where it was observed at Dolé, Sainte Marie, Sainte Rose, Bonne Mere, and the hills behind Goyave, and none were seen on Grande Terre. A female collected at Dolé on June 17 had eaten two green Anotis lizards.

Les Saintes: Noble obtained a specimen. Commoner than on Guadeloupe. The stomach of a female collected on Terre-de-Bas July 5, 1937 contained a large Anotis lizard and 7 large pieces of gravel, while another female taken on Terre-de-Haut the same day had eaten a centipede and a ground lizard (Ameiva).

Désirade: Collected by Richardson in 1886. On July 9, 1937 five were observed on top of the plateau, and a female was collected. Its stomach contained short-horned grasshoppers.

Marie Galante: Collected by Richardson in 1886.

$$
\begin{gathered}
\text { Colinus virginianus virginianus (Linnaeus) } \\
\text { BOB-WHITE or QUAIL }
\end{gathered}
$$

Guadeloupe: According to Phillips (U.S.D.A. Tech. Bull. 61, 1928, p. 31) the species was introduced in Guadeloupe about 1886-87. Apparently it was soon exterminated, as there are no further records.

Rallus longirostris manglecola Danforth

ANTIGUA CLAPPER RAIL

Pintade Maronne

Guadeloupe: Apparently formerly not uncommon, as there are 7 
unlabelled specimens supposedly from Guadeloupe (one of which is immature) in the Musé L'Herminier. Noble stated that in 1914 the species had apparently been extirpated by the mongoose, not having been taken by the native chasseurs for a long time. An extensive search of all likely mangrove swamps we could locate failed to reveal any of these rails in 1937. Measurements were taken of the 6 adult specimens in the Musée L'Herminier. The culmen from base ranged from 63.3 to 73 millimeters (average 67.1 ) and the tarsus from 47.3 to 51.6 (average 49.4), thus agreeing well in size with specimens from Antigua. There is an immature specimen said to have been collected in Guadeloupe by Ober in the U. S. National Museum.

\section{Ionornis martinica (Linnaeus)}

\section{PURPLE GALLINULE}

\section{Poule d'eau á Cachet Vert}

Guadeloupe: Apparently extremely rare. The only definite record I find is of an adult purchased by Noble at Le Moule, Grande Terre, taken in 1913.

\section{Gallinula chloropus portoricensis Danforth ANTILLEAN GALLINULE \\ Poule d'eau á Cachet Rouge}

Guadeloupe: There are numerous old records, but Noble considered the species almost extinct in Guadeloupe in 1914. He obtained a pair. We observed none in 1937.

Marie Galante: Collected by Richardson in 1886. In 1937 we observed two and collected a male in a sluggish stream at Saint Louis on July 18. Its stomach contained fragments of molluse shells and seeds.

\section{Fulica caribaea Ridway CARIBBEAN COOT}

Poule d'eå á Cachet Blanc

Guadeloupe: There are two specimens in the U.S. National Museum taken many years ago by Guesde. 
THE JOURNAL OF AGRICULTURE OF THE UNIVERSITY OF P. $R$.

Haematopus palliatus prattii Maynard

BAHAMAN OYSTER-CATCHER

Casse-Burgeau

Guadeloupe: In the Musée L'Herminier there are four unlabelled mounted specimens presumably from Guadeloupe. The culmen from base of these specimens measured $83,85.5,89.9$ and 92.3 millimeters. In the U.S. National Museum there is a specimen taken on Guadeloupe by Guesde.

\section{Pluvialis dominica dominica (Müller) GOLDEN PLOVER}

Guadeloupe: Listed by Ober.

Charadrius semipalmatus Bonaparte SEMIPALMATED PLOVER

Guadeloupe: There is an adult male in the British Museum collected on September 6, 1890 by Winch. Ober also obtained a specimen.

\section{Totanus melanoleucus (Gmelin) \\ GREATER YELLOWLEGS \\ Clinclin}

Guadeloupe: One was observed at Port-Louis, Grande Terre on July 8, 1937. Although this and various other unlisted shorebirds are probably of common occurrence, there was no definite previous record.

\section{Tringa solitaria solitaria Wilson \\ SOLITARY SANDPIPER}

Guadeloupe: Obtained by Ober in 1878 and by Winch in 1890 . Actitis macularia (Linnaeus)

SPOTTED SANDPIPER

Branle-queue

Guadeloupe: First recorded by Colardeau. The Field Museum has a female collected August 12, 1890 by Winch. Noble found it early in July, and on that account believed it to be resident. We observed two at Port-Louis, Grande Terre on July 8, 1937. 
Limnodromus griseus griseus (Gmelin)

EASTERN DOWITCHER

Becasse Grise

Guadeloupe: Lincoln (in Book of Birds, II, 1937, p. 352) records a specimen banded at North Eastham, Massachusetts on July 31, 1935, and captured at Pointe-á-Pitre on August 26, 1935. All other records, except possibly that of Mimi, apparently originate from L'Herminier's list.

\section{Ereunetes pusillus (Linnaeus)}

SEMIPALMATED SANDPIPER

Guadeloupe: Listed by Ober in 1878. The Field Museum has a female collected September 11, 1890 by Winch.

Pisobia minutilla (Vieillot)

LEAST SANDPIPER

Guadeloupe: Listed by Ober. The Field Museum has three males and a female collected by Winch on September 4, 1890.

Pisobia melanotos (Vieillot)

PECTORAL SANDPIPER

Guadeloupe: Listed by Ober. The British Museum has a female collected ${ }^{-S e p t e m b e r ~ 2,1890 ~ b y ~ W i n c h . ~}$

\section{Larus.atricilla Linnaeus \\ LAUGHING GULL \\ Pigeon de Mer}

Guadeloupe: Apparently not very common on the coasts of Guadeloupe. Recorded by Ober. The British Museum has an adult male collected in August 1890 by Winch. Noble observed a few near Goyave in the latter part of August 1914. We observed none in 1937.

\section{Sterna hirundo hirundo Linnaeus \\ COMMON TERN \\ Petite Mauve}

Guadeloupe: Sent by Dr. Colardeau to Lawrence in 1885. 


\section{Sterna dougalli dougalli Montagu \\ ROSEATE TERN \\ Mauve á Bec Noir}

Guadeloupe: Winch collected a series September 20-24, 1890, which is now in the British Museum. Noble reports it as seen rarely along the coast of Guadeloupe, and as reported by fishermen to breed on Tête Anglais.

Les Saintes: Fishermen reported it to Noble as breeding on Les Saintes, and he obtained an adult female there on September 10, 1914. We observed many, apparently nesting, on Terre-de-Bas and Grand Ilet on July 5, 1937.

Marie Galante: We observed five along the west coast on July. 17, 1937, and two at Saint Louis the following day. Not previously recorded from the island.

\section{Sterna anaetheta melanoptera Swainson BRIDLED TERN Mauve á Manteau Noir}

Guadeloupe: The British Museum has an adult male and three inmature specimens taken by Winch in September, 1890.

\section{Sterna fuscata fuscata Linnaeus \\ SOOTY TERN \\ Mauve á Manteau Noir}

Guadeloupe: Ober obtained a full grown young in 1878. Fishermen reported it to Noble as breeding on outlying islets. On July 9, 1937 we observed thousands breeding on Le Souffloeur, a rock off the extreme eastern point of Grande Terre, while passing in a motor launch. Possibly there were a few Bridled Terns among them, but all which could be seen distinctly enough for satisfactory identification were this species. Some were seen at sea about half way from there to the island of Désirade.

Les Saintes: Noble obtained an adult female on September 10, 1914. On July 5, 1937 we observed three at Terre-de-Haut.

\section{Sterna albifrons antillarum (Lesson) \\ LEAST TERN \\ Petite Mauve}

Guadeloupe: Obtained by Winch in 1890 . 
Thalasseus maximus maximus (Boddaert)

ROYAL TERN

Guadeloupe: Listed by Ober, and reported to Noble as breeding on Tête Anglais.

Les Saintes: Fishermen told Noble it nests. However, its nesting anywhere in the Guadeloupe region is a matter of considerable doubt.

\section{Anoüs stolidus stolidus (Linnaeus) \\ NODDY TERN \\ Mwen. Minine.}

Guadeloupe: Collected by Winch in 1890. Noble reported it as rare about the mainland of Guadeloupe, but as reported to breed on Téte Anglais.

Les Saintes: Reported to Noble as breeding. . On July 5, 1937 we found it nesting commonly on Grand Ilet and on the cliffs on Terre-de-Bas, and observed a few (apparently not nesting) around Terre-de-Haut.

\section{Columba leucocephala Linnaeus}

WHITE-CROWNED PIGEON

\section{Ramier á Tête Blanche}

Guadeloupe: Apparently a rare and irregular visitor. Rigdway's record seems to be based on L'Herminier, but Mimi mentions the bird, and it was reported to Noble as being occasionally seen after hurricanes.

\section{Columba squamosa Bonnaterre}

\section{SCALED PIGEON}

\section{Ramier}

Guadeloupe: This is the most important game bird of the island, being killed in large numbers every year by sportsmen and market hunters, bringing rather high prices. At the time of our visit the standard price was 7 franes (then nearly 35 cents). It is found most abundantly in the rain forests, although it also occurs in the lower wooded hills. We found it less common than in many nearby islands, probably due to the greater persecution it receives here.

Les Saintes: On July 5, 1937 a few were observed on Terre-deHaut, and it was common on the mountain on Terre-de-Bas. Not previously recorded.

Marie Galante: Five seen at Trois Islets and three at Saint Louis on July 18, 1937 . Not previously recorded. 


\section{Zenaida aurita aurita (Temminck)}

\section{MARTINIQUE DOVE}

Tourterelle

Guadeloupe: Common in lower regions of second growth woods. We observed it at Dolé, Goyave, Sainte Marie, and Vieux-Bourg (Grande Terre).

Les Saintes: 10 seen on Terre-de-Haut July 5, 1937 constitute the first record.

Désirade: On July 9, 1937 we observed 10. Not previously recorded.

Marie Galante: Ten observed and a male collected at Trois Islets on July 18, 1937. Its crop was crammed with an enormous number of Bignoniaceous seeds, and 2 fruits of Solanum bahamensis. Not previously recorded from the island.

\section{Columbigallina passerina nigrirostris Danforth}

\section{ST. KITTS GROUND DOVE}

\section{Ortolan}

Guadeloupe: Common and well known. We found it much more common on the west than on the east coast of Guadeloupe proper, being particularly abundant from Vieux Habitants to Malendure. On Grande Terre it was locally common. Females were collected at Dolé June 23; Goyave July 2; Malendure July 4; Vieux-Bourg, Grande Terre July 13, and Le Moule, Grande Terre, July 16, 1937. All had the bill entirely dusky. All the crops were filled with small seeds, among which those of Euphorbeaceae figured prominently.

Les Saintes: Fairly common on Terre-de-Bas and ten were seen on Terre-de-Haut on July 5, 1937. A male collected on Terre-deBas had a completely dusky bill. Not previously recorded.

Désirade: Collected by Richardson in 1886. On July 9, -937 we found it common, and collected an immature male and an adult female, both with dusky bills. Not previously recorded.

\section{Oreopeleia mystacea mystacea (Temminck) \\ BRINDLED QUAIL DOVE \\ Perdrix Croissant}

Guadeloupe: Obtained by most collectors. Richardson obtained it on Grande Terre in 1886, where it is doubtful if it occurs at present. Noble found it locally abundant, and collected 15 specimens in 
1914. In 1937 we observed a few at Sainte Marie on various dates, and collected a female on June 30. Its crop contained two large nuts and some soft fruits. We also recorded the species at Bananier and Sainte Rose.

Les Saintes: Recorded by Bond. We observed three on the higher parts of the mountain of Terre-de-Bas on July 5, 1937.

Désirade: Listed by Bond.

\section{Oreopeleia martinica (Linnaeus)}

MARTINIQUE QUAIL DOVE

Perdrix Rouge (male); Perdrix Gris (female)

Guadeloupe: Formerly abundant, but Noble considered it to be the rarest bird in Guadeloupe in 1914. He obtained one specimen at Goyave. In 1937 we observed a female in the mountains west of Bonne Mere on July 15.

Coccyzus minor dominicae Shelley

SHELLEY'S MANGROVE CUCKOO

Coucou Manioc. Oiseau de Pluie.

Guadeloupe: Found rather uncommonly in the second growth on hills, where we observed it only in the hills behind Goyave, at Boullante, and at Vieux-Bourg (Grande Terre).

\section{Crotophaga ani Linnaeus}

ANI

Merle Corbeau; L'Ami des Savanes

Guadeloupe: Of doubtful occurrence. A planter told Noble that it had been seen after hurricanes.

Les Saintes: Recorded by Mimi. On July 5, 1937 we found it perhaps the commonest bird on Terre-de-Haut, frequenting pastures and brushy land, but observed none on Terre-de-Bas. A pair was collected. One stomach contained 15 weevils, Lachnopus curvipes, and the other 6 Lachnopus curvipes and a grasshopper.

Speotyto guadeloupensis guadeloupensis Ridgway MARIE GALANTE BÜRROWING OWL

\section{Coucou}

Guadeloupe: Although listed by many authors, there is no evidence that it ever existed there. 
Marie Galante: Formerly found on the cliffs, now exterminated by the mongoose. I have examined four specimens in the Musée L' Herminier; a fifth was presented by them to the Museum of Comparative Zoölogy.

\section{Nephoecetes niger niger (Gmelin)}

ANTILLEAN BLACK SWIFT

Hirondelle de Montagne; Gros Martinet Noir

Guadeloupe: Winch collected 23 specimens in 1890, one of which (a female collected on August 11) is the type of Cory's Nephoecetes niger guadeloupensis. Noble found it abundant on the edges of the Grand Bois, and collected three at Goyave on September 1, 1914. In 1937 we found it common in the hills behind Goyave on June 21 and at Sainte Marie on June 24 and 25, and observed a few at Capesterre June 14, Matouba July 1, and Bonne Mere July 15.

\section{Chaetura acuta (Gmelin)}

\section{LESSER ANTILLEAN SWIFT}

\section{Petit Martinet Noir; Hirondelle-Mouche}

Guadeloupe: Ober observed the species but obtained no specimen. Winch obtained one, and Dr. Colardeau sent another to Lawrence, which became his type of Chaetura dominicana colardeaui. Noble obtained 11 at Goyave August 29 and 30, 1914. We found it common at Dolé on June 16,1917, but observed none there on other days; and abundant in the hills behind Goyave on June 21. Lesser numbers were observed at Basse-terre, Morne Folie, the Soufrière Mountain, Matouba, Trois Rivieres, Sainte Marie, and Sainte Rose.

\section{Orthorhynchus cristatus exilis (Gmelin) \\ GILT-CRESTED HUNMINGBIRD \\ Fou-Fou; Oiseau-Mouche Huppé}

Guadeloupe: Common and generally distributed, observed from the coast to high elevations on the Soufrière. On July 2, 1937 a nest with 2 eggs was found 6 feet from the ground attached to a twig of a tree in the second growth forest. The nest was the usual structure of fine plant fibers plastered outside with lichens. The incubating female sat very closely.

Three adult males, two adult females, two immature specimens, and one of undetermined sex were collected at various localities in 1937. The contents of 6 of the 8 stomachs were examined, and found 
to consist of small spiders 65 per cent, and insects 35 per cent (including minute Coleoptera 5 per cent and small winged ants 8.2 per cent).

Les Saintes: Common on both Terre-de-Bas and Terre-de-Haut on July 5, 1937. A female was collected on the former, and a male on the latter. Not previously recorded.

Désirade: Collected by Richardson in 1886. We found it common on July 9, 1937, and collected a pair. One stomach contained small black ants, and the other small spiders.

Marie Galante: The Field Museum has 9 specimens collected by Richardson in 1886. We found it common on July 18, 1937, and collected a pair at Trois Islets. One of the stomachs contained minute Coleoptera.

\section{Sericotes holosericeus holosericeus (Linnaeus)}

\section{BLUE-BREASTED HUMMINGBIRD}

\section{Colibri Bleu; Oiseau-Mouche Blue}

Guadeloupe: In June and July, 1937 we found this species common at Dolé, Bananier, Goyave and Sainte Marie, and observed a few at Vieux-Bourg (Grande Terre). On December 29, 1930 six were observed at Ste. Claude. Four males and two females were collected in 1937. The six stomachs contained spiders 21.7 per cent; small brown winged ants 36.6 per cent; Coleoptera 23.3 per cent (including a small Chrysomelid, a small weevil, a small ladybird beetle, Scymnillodes sp., and many others); minute wasps 13.3 per cent; Diptera 1.7 per cent, and other insects 3.4 per cent.

Désirade: There are 2 specimens in the Field Museum collected by Richardson in 1886 .

Marie Galante: The Field Museum has 3 specimens collected by Richardson in 1886. We saw three at Trois Islets on July 18, 1937.

\section{Eulampis jugularis (Linnaeus)}

\section{GARNET-THROATED HUMMINGBIRD}

\section{Gros-Colibri. Oiseau Mouche a Gorge Rouge}

Guadelouipe: Common in all wooded regions, although showing a preference for higher altitudes. However, at Sainte Marie it was abundant in lowland woods, and some were even seen in a wooded swamp close to the edge of the sea. A male and three females were collected. Their stomach contents consisted exclusively of insects, among which ants (mostly winged) formed 34 per cent; minute Bostrichid beetles 2.5 per cent: small Diptera 12.5 per cent; coffee 
lantern flies, Bothriocera venosa, 15 per cent; and small Lepidopterous larvae 15 per cent.

Les Saintes: Recorded by Bond.

Désirade: Recorded by Bond.

Marie Galante: Recorded questionably by Bond; reason not stated.

Magaceryle alcyon alcyon (Linnaeus)

BELTED KINGFISHER

Pie de Mer

Guadeloupe: First listed by Ober. There is a male collected September 28, 1890 by Winch in the Field Museum.

\section{Megaceryle torquata stictipennis (Lawrence) RINGED KINGFISHER}

Pie

Guadeloupe: This giant species has been recorded by various authors, and Noble found a nesthole in high sandbanks along the Rivière de Goyave in the spring of 1914, and obtained a specimen. The type was obtained by Dr. Colardeau in 1885 . There are several specimens in the Musèe L'Herminier. It is found locally along wooded streams, but is extremely wary. We observed it upon four occasions in 1937. One flew high over the hotel at Dolé on June 15; one was seen along a wooded, lowland stream near Sainte Marie on June 24 and again the next day, when it was shot and injured but not recovered; and one was observed in the mountains west of Bonne Mere on July 15.

\section{Melanerpes herminieri (Lesson) \\ GUADELOUPE WOODPECKER \\ Tapeur}

Guadeloupe: This woodpecker, notable as being the only representative of its family in the Lesser Antilles, is not rare, but is very locally distributed, mostly in the low heavily wooded hills of the northeastern part of Guadeloupe proper. We saw it only once in the interior mountains (one in the mountains above Matouba on July 1). We found it most common at elevations of about 500 feet in wooded hills back of Sainte Marie, Goyave, Bonne Mere, and Sainte Rose, frequently mostly on dead trees. Its call note is a loud, harsh gu-r-r-r-r-rh, extremely different from that of $M$. portoricensis. 
At times it beats tattoos on the wood. It is not at all shy, and appears all black in the field. A male and four females were collected. An adult male collected near Sainte Marie on June 30, 1937 had the iris dark brown; bill black; legs and feet bluish slate-gray; claws dusky; soles dull yellow. Four of the stomachs contained insects and their larvae 93 per cent (Cerambycid beetles 37.5 per cent; other Coleoptera 16.2 per cent; Muscid fly 2.5 per cent; small ants 0.7 per cent; miscellaneous insects 36.1 per cent, and a seed 7 per cent.

\section{Tyrannus dominicensis vorax Vieillot}

\section{LARGE-BILLED KINGBIRD}

\section{Pipirit}

Guadeloupe: Common in the lowlands, and occasionally observed at lower elevations in the mountains. Four females (one of them immature) were collected. The three adults measured: culmen from base 32.4-34 (33.2), and width at frontal antiae 15.9-16 (15.9) millimeters. They are clearly vorax. Ridgway records dominicensis from the Island, but it seems likely that his specimen was an intergrade, such as are often found in the northern Lesser Antilles. Four stomachs contained wasps 75 per cent ( 15 per cent of them Polistes); 3 weevils, Diaprepes spengleri (in one stomach), 10 per cent; small drupes 15 per cent.

Désirade: Common on July 9, 1937. The stomach of an immature specimen collected contained wasps (30 per cent) and grasshoppers (70 per cent). Not previously recorded.

Marie Galante: Common on July 18, 1937. A male collected at Trois Islets measured, culmen from base 34.9 and width at frontal antiae 15.5 millimeters. Its stomach contained a dragonfly (Erythrodiplax umbiata) 70 per cent, and Coleoptera, 30 per cent. Not previously known from the Island.

\section{Myiarchus tyrannulus oberi Lawrence OBER'S CRESTED FLYCATCHER \\ Pipirit Gros-Tête}

Guadeloupe: Although Dr. Colardeau gave some information concerning this species (saying it was not rare in some parts of the mountains), the only positive record is of two birds seen and an im. mature male collected by Noble at Sainte Rose on July 11, 1914. 
Blacicus brunneicapillus Lawrence

DOMINICAN PEWEE

Gobe-Mouche Brun

Guadeloupe: Winch obtained 4 specimens in 1890. Noble found it not rare but local, obtaining 1 specimen on the Soufrière and 8 at Sainte Rose. We encountered only four individuals during our stay, a male which was collected at Morne Folie on June 18, 1937, and three on the Soufrière on June 29, one of which, a female, was collected. The two stomachs contained exclusively insects, among which Coleoptera formed 52.5 per cent and Hymenoptera 35 per cent.

\section{Elaenia martinica martinica (Linnaeus)}

ANTILLEAN ELAENIA

Petit Pintade; Gobe-Mouche Huppé

Guadeloupe: Abundant and generally distributed, from the mountain forests to the seacoast. Six males and three females collected proved to be typical martinica, and I have given their measurements elsewhere (Journal of the Barbados Museum and Historical Society, vol. 5, 1938, pp. 124-125). The contents of five of the stomachs was examined, and found to consist of animal matter 10 per cent (a nymh opf Phymata sp., and a spider), and vegetable matter 90 per cent (fruits and seeds of Solanum bahamensis 30 per cent; other berries and fruits 60 per cent).

Les Saintes: Common on Terre-de Bas July 5, 1937 (when a female was collected), and observed on Terre-de-Haut. The stomach of the specimen collected contained a few fragments of fruits. Not previously recorded.

Désirade: There are 6 specimens in the Field Museum obtained by Richardson in 1886. We recorded 10 on July 9, 1937.

Marie Galante: Richardson obtained 5 specimens in 1886. We found it common at Trois Islets on July 18, 1937, and collected a female, the stomach of which was filled with small black drupes.

\section{Hirundo erythrogaster Boddaert \\ BARN SWALLOW \\ Hirondelle}

Guadeloupe: In the U. S. National Museum there is a specimen collected by Ober. 


\section{Progne dominicensis (Gmelin) \\ CARIBBEAN MARTIN}

\section{Hirondelle at Dominique}

Guadeloupe: Apparently unknown from here until Noble's visit. In 1914 he found it not rare on the east coast of Guadeloupe proper and on Grande Terre, and obtained 6 specimens at Goyave August 30 and 31. We found it common, observing it at Basse-Terre, Bananier, Capesterre; and Port-Louis, Pointe-a-Pitre and Le Gosier, Grande Terre. A male was collected at Bananier on June 28, 1937, and two males and a female at Port-Louis on July 8, 1937. At the latter locality the birds frequented an extensive mangrove swamp with dead trees scattered through it. The first stomach was filled with comminuted insects, mainly Pentatomidae. The latter three contained Syrphie flies (Volucella obesaQ, 35 per cent; wasps 24.7 per cent; Carabid beetles 8.3 per cent; Hydrophilid Beetles (Tropisterna collaris), 19 per cent; an all black species of Tropisterna, 7.3 per cent; bean fleabeetles (Cerotoma ruficornis), 2.7 per cent; a dragonfly, 12 per cent.

Les Saintes: On July 5, 1937 we found it breeding on the cliffs on both Terre-de-Bas and Terre-de--Haut. Not previously recorded.

Désirade: Two seen on the plateau, July 9, 1937. First record for the Island.

Marie Galante: A few were observed at Trois Islets on July 18, 1937. First record.

\section{Troglodytes guadeloupensis (Cory) \\ GUADELOUPE WREN}

Rossignol

Guadeloupe: Formerly common; now probably extinct. Last seen in 1914 by Noble in high woods that had been cut over near Sainte Rose. He obtained a female on July 13. The type locality is in Grande Terre.

\section{Allenia fusca (Miller) \\ SCALY-BREASTED THRASHER \\ Grive Fine}

Guadeloupe: Common on the wooded hills of Guadeloupe proper. One example was seen at Vieux-Bourg, Grande Terre on July 13, 1937. Adult males were collected near Goyave on July 21, Trois Rivieres June 22, and Sainte Marie June 24; a juvenile male at 
the latter locality June 30, and a female at Sainte Rose JuIy 12. One of the stomachs was empty; the other four contained berries and drupes, 54 per cent; seeds of Oleaceae 20 per cent; other seeds 1 per cent; a land snail 8 per cent, and 2 slugs 17 per cent.

Désirade: Richardson obtained one in 1886.

Marie Galante: Listed by Cory, although it is not included in the list of specimens obtained by Richardson, and there is no specimen from there in the Field Museum. We found it common at Saint Louis on July 18, 1937, and collected a male; we also observed one near the coast at Trois Islets. The stomach of the specimen collected contained drupes and berries.

\section{Margarops fuscatus densirostris (Vieillot)}

\section{BARKER PEARLY-EYED THRASHER}

Grosse Grive

Guadeloupe: This species is persecuted so much as a game bird that it has become very shy and wary. It is found in the rain forest, where we observed it commonly on Morne Folie and on the Soufrière.

Désirade: Richardson obtained 12 specimens in 1886 . We found it common on the sides of the mountain on July 9, 1937, and collected two males. Their stomachs contained drupes, 56 per cent, and a long-horned grasshopper, (Neoconocephalus), 44 per cent.

\section{Cinclocerthia ruficauda tremula (Lafresnaye) GUADELOUPE TREMBLER}

Trembleur; Grive Trembleuse

Guadeloupe: Found only in dense woods, both on the higher mountains and on the hills of lower elevation. One is almost sure to come across two or three during the course of a morning's field work in such regions. An adult male, 3 adult females, and 2 immature females were collected at Morne Folie, the Soufrière, Goyave, Sainte Rose, and the mountains west of Bonne Mere. Seven stomachs (including that of a specimen too damaged to save) contained exclusively fruits and seeds, with the exception of some Mantid fragments in one stomach amounting to 8 per cent of the total contents. Of the remaining 92 per cent, soft Araceous seeds formed 52 per cent; soft, fleshy berries 20 per cent; gelatinous-coated seeds 14 per cent, and other seeds 6 per cent. 
A female collected at Morne Folie June 18, 1937 had the iris bright golden yellow; bill black; legs and feet yellowish brown, more or less tinged with gray above, including the claws; soles yellow.

An adult male measured, wing 104.3; tail 89; culmen from base 35.9 ; tarsus 30.5 , Three adult females meausred, wing 98.6-101.4 (99.8); tail 83.3-88 (85.9); culmen from base 40.5-42.5 (41.3); tarsus 30-32 (31.3) millimeters.

These specimens are much like specimens of C.r. tenebrosa in color, but are very slightly darker on the upper surface, particularly upon the wings, and slightly more rufescent below.

There are 2 specimens from Grande Terre in the Field Museum collected by Richardson in 1886, but it is doubtful if the species occurs there at present.

\section{Cichlherminia lherminieri therminieri (Lafresnaye)}

\section{GUADELOUPE FOREST THRUSH}

\section{Grive a Pieds Jaunes}

Guadeloupe: Formerly common, and an important game bird, but due to its ground-frequenting habits it fell an easy prey to the mongoose. However, Noble thought it was adapting itself by abandoning its terrestrial habits and possibly becoming somewhat more common in 1914, when he obtained 24 specimens from near Sainte Rose and Goyave. Nevertheless, in 1929 Breta reported it to Bangs as extinct or nearly so. In 1937 we observed a few on the lower parts of the Soufrière on June 29, and found the species in limited numbers in rather low hardwood forests near Sainte Marie, Goyave, and west of Bonne Mere, a total of somewhat over twenty birds being observed during the course of our visit, so it is evident that, while not common, it is far from extinct.

On June 30 in a rather low hardwood forest in a stream valley in foothills near Sainte Marie a family consisting of the parent birds and three young just out of the nest was encountered. Two of the young were able to fly slightly, the thirds not at all. When the latter was captured alive its cried brought the parents around. They generally kept a safe distance away, flitting nervously from tree to tree, keeping from 5 t 20 feet above the ground, and uttering soft tuck, tuck alarm notes, and quite a variety of scold notes. Occasionally they dashed much closer uttering lound complaining screeches. The male was always the boldest, so it was collected, but the female was much more cautious and always kept more in the 
background, so it proved impossible to collect it. Directly above the spot where the young unable to fly was found was an empty nest from which it appeared probable it had fallen. It was in a tree at a height of 35 feet above the ground, at the point where some small leaves shaped somewhat like those of the banana plant but shorter and stouter, sprouted directly from the trunk, which was bare up to this point, and was secured to the bases of those leaves. Externally it was constructed almost entirely of gray mosses loosely woven together.

Two of the young as well as the male parent were preserved as specimens. The adult male had the iris hazel; bare orbital ring. golden yellow; upper mandible dusky, more or less tinged with yellow; legs and feet golden yellow, claws slightly tinged with dusky. One of the juveniles (a male, unable to fly) had the iris hazel; bare orbital ring dusky brown; upper mandible dusky brown, slightly tipped with horn color; fleshy base of both mandibles dull white; lower mandible horn color more or less tinged with dusky; inside of mouth dull orange yellow; legs and feet pearly gray more or less tinged with straw color; back of legs and soles straw color.

Another adult male was collected in the mountains west of Bonne Mere on July 15, 1937. The measurements of the two adult males are given in my paper on the birds of Montserrat elsewhere in this same Journal.

All specimens that we observed were in trees never closer than four feet to the ground.

The intestines of the juvenile bird which could fly slightly contained a large tapeworm, which I have preserved for possible future identificación. The stomach of this individual contained fruit $(90$ per cent), and bones of a small lizard (10 per cent). The stomach of the other juvenile was nearly empty, containing only the mandibles of what had evidently been a strong-jawed coleopterous larva. The stomach of the male parent was very large and was crammed with 14 dark-colored drupes 8-9 millimeters in diameter. The other male had eaten three large drupes.

Vireo calidris barbadensis (Ridgway)

BARBADOS VIREO

Siffleur; Piade

Guadeloupe: A well known summer resident and breeder, but it is doubtful if it occurs in the winter. The latest definite records I can find are of specimens taken by Ober in September. It is fairly 
common in wooded regions, both in the high mountain forest and in the foothills. The following specimens were collected in 1937: Adult male, Dolé, June 16; inmature, Trois Rivieres, June 22 ; adult male, Vieux-Bourg, Grande Terre, July 13; adult male and adult female, Le Moule, Grande Terre, July 16. The five stomachs contained 33 per cent of insects (Hemiptera, a click-beetle of the genus Monocrepidus, weevils and other Coleoptera), and 67 per cent of small fruits (drupes, berries, and the soft seeds of Araceae).

Les Saintes: On July 5, 1937 it was common on Terre-de-Bas (where a male? was collected), and it was observed on Terre-de-Haut. The stomach of the specimen collected contained drupes. Not previously recorded.

Désirade: On July 9, 1937 two fighting birds (one definitely a male, the other probably so) were collected at one shot; no others were seen or heard. The stomachs contained drupes and berries 97.5 per cent, and Coleoptera 2.5 per cent. First record for the island.

Marie Galante: There are two specimens in the Field Museum collected by Richardson in 1886. We found it common on July 18, 1937, and collected a male at Trois Islets. Its stomach contained drupes 70 per cent and insects 30 per cent (fleabeetles 15 per cent).

\section{Coereba bartholemica (Sparrmann)}

ST. BARTS HONEY CREEPER

\section{Sucrier}

Guadeloupe: Common practically everywhere; probably the most abundant and universally distributed bird on the island. Three adult males, two adult females, and three immature specimens were collected at Dolé, Fond Cabe, Sainte Marie, Bananier, Malendure, and Le Moule (Grande Terre). These specimens differ in nowise from specimens from islands to the north, so I regard them as barthotemica. Three adult males measure: Wing 60.8-63.2 (62); tail 39-41.4 (40); culmen from base 16-17.5 (16.9) ; tarsus 18.1-18.7 (18.4), and two adult females, wing 53.5-58 (55.75); tail 35.3-37.4 (36.35) ; culmen from base 16-16.6 (16.3) ; tarsus 16.6-17.9 (17.25) millimeters. One of the males has the frontal region partly white.

Stomachs of five of the specimens contained spiders 17 per cent, and insects and their larvae and eggs 83 per cent, including lepidopterous larvae 16 per cent, small Coleoptera 14 per cent, Diptera 4 per cent, and ants 4 per cent. 
Les Saintes: First recorded by Bond. Common on Terre-de-Bas July 5, 1937, where an adult male was collected, but curiously none were observed on Terre-de-Haut. The specimen collected measured, wing 61.7 , tail 39 , culmen from base 16.7 , and tarsus 18.6 millimeters. Its stomach contained 2 lepidopterous larvae and some fragments of Coleoptera, plus a few grains of sand.

Désirade: Richardson obtained two in 1886. We observed a few near the coast on July 9, 1937.

Marie Galante: Richardson collected six in 1886. In 1937 we found it common at Trois Islets and collected an adult male on July 18. It measured, wing 63.2 , tail 41.8 , culmen from base 16.2 , tarsus 19.2 millimeters. Its stomach contained small lepidopterous larvae, and fragments of eggshell.

\title{
Mniotilta varia (Linnaeus)
}

BLACK AND WHITE WARBLER

Demi-Deuil

Guadeloupe: Dr. Colardeau reported it as rather common from the end of October to the beginning of May.

\section{Compsothlypis americana pusilla (Wilson)}

\author{
NORTHERN PARULA WARBLER
}

Guadeloupes Dr. Colardeau reported it as not plentiful, from December to March.

\section{Dendroica tigrina (Gmelin) \\ CAPE MAY WARBLER}

Guadeloupe: Dr. Colardeau sent three specimens to the U. S. National Museum, one of them obtained in his yard in Basse-terre. He usually found them in coffee shade trees in the mountains, reporting it from November to April.

\section{Dendroica petechia ruficapilla (Gmelin) \\ GUADELOUPE GOLDEN WARBLER \\ Oiseau Jaune; Petit Jaune}

Guadeloupe: Very common in the lowlands, in clearings, scrub country, and mangrove swamps, but never seen in the woods. Observed as high as Ste. Claude in clearings. One adult male, six 
females, and one juvenile specimen were collected at Dolé, Trois Rivieres, Bananier, Sainte Marie, Vieux-Bourg (Grande Terre), and Le Moule (Grande Terre).

The adult male measures, wing 59.2 , tail 43.7 , culmen from base 14, tarsus 19.4 millimeters, and the 6 females, wing 54.3-55.5 (54.8); tail (in five) 42.6-44.2 (43.4); culmen from base 13.1-14.6 (14.1); tarsus 18.2-19.6 (18.8) millimeters.

Eight stomachs contained vegetable matter 5.4 per cent (small seeds in two stomachs), and animal matter 94.6 per cent (spiders 6.2 per cent; ticks 2 per cent; insects and their larvae 86.4 per cent, including Orthoptera, Hemiptera, fleabeetles, weevils and other Coleoptera; small winged ants, and other Hymenoptera).

Les Saintes: Recorded by Bond. We found it common on both Terre-de-Bas and Terre-de-Haut on July 5, 1937, and collected an adult male on the former. It measured, wing 58.3, tail 44.1, culmen from base 14.6, and tarsus 18.7 millimeters. It had eaten an aphid, some beetles, and some unidentified insects.

Désirade: First recorded by Bond, who found it rather rare. On July 9, 1937 we found it common near the coast, and observed a few on the plateau and on the sides of the mountain. An adult male was collected, which measured, wing 56.7, tail 42.7, culmen from base 14.6, and tarsus 20.2 millimeters. It had eaten a small weevil, other Coleoptera, and some other insects.

Marie Galante: Richardson collected 4 specimens in 1886. On July 17 and 18, 1937 we found it abundant, recording it at Grand Bourg, Trois Islets and Saint Louis. An adult male collected at Trois Islets on July 18 measured, wing 56.6, tail 42.6, culmen from base 14.6, and tarsus 19 millimeters. Its stomach contained 95 per cent of fleabeetles, and 5 per cent of miscellaneous insects.

\section{Dendroica plumbea guadeloupensis Brodkorb}

GUADELOUPE PLUMBEOUS WARBLER

Fauvette Gris; Petite Pintade

Guadeloupe: This bird is fairly common wherever deep woods are found, both in the high mountain forests and in the foothills. In travelling through the great lonely woods, where all birds are chiefly conspicuous by their scarcity (often one may travel for half an hour without observing a single bird), the first bird one is likely to encounter is this. Most of what birds there are in these great woods seem to congregate in particular "cases", as likely as not in 
some pocket by a stream valley, where a fairly large congregation of individuals representing several species may be found. But far away from these "oases", in fact at almost any point, the monotony and gloom of the uncannily silent forest may be suddenly and unexpectedly broken by coming across either a single bird or a small family group of these warblers. For this reason they became particular favorites of ours.

Its song is weak and inconspicuous, consisting of three syllables. The call note is an equally inconspicuous tcheck, but at times it utters loud, rattling scold notes, somewhat similar to those of some wrens. As it works through the brush its long tail is made even more noticeable by the frequency with which it twitches it.

Fourteen specimens ( 6 adult males, 1 immature male, 2 immature females, and 5 unsexed immature and juvenile specimens) were collected on the Soufrière and Morne Folie, and in woods near Matouba, Trois Rivieres, Goyave, Bananier, Sainte Marie, Bonne Mere and Sainte Rose. An adult male collected June 18, 1937 on Morne Folie had the iris dark brown; upper mandible dusky, lower horn color slightly tinged with dusky at the tip; legs and feet brownish straw color; soles yellow; claws yellowish brown.

The fourteen stomachs contained spiders 9.6 per cent; a small lizard 0.7 per cent; Fulgoridae 5 per cent; other Homoptera 4.3 per cent; large Staphylinid beetles 2.9 per cent; weevils 8.4 per cent; other Coleoptera 10 per cent; Lepidopterous larvae 5.7 per cent; miscellaneous comminuted insects 53.4 per cent.

\section{Dendroica plumbea plumbea Lawrence}

DOMINICA PLUMBEOUS WARBLER

Fauvette Gris

Marie Galante: Richardson obtained 8 specimens in 1886, which are stated by Brodkorb to represent the Dominican race. There is no country on Marie Galante now which would seem to be suitable for this bird, and I doubt very much if it still exists there.

\section{Dendroica breviunguis (Spix)}

\section{BLACK-POLL WARBLER}

Guadeloupe: Dr. Colardeau observed great numbers for eight or ten days in October, 1882, and obtained a specimen in the Botanic Gardens at Basse-terre on October 10. In 1883 he was unable to find any. 
THE BIRDS OF GUADELOUPE AND ADJACENT ISLANDS

Dendroica virens virens (Gmelin)

BLACK-THROATED GREEN WARBLER

Guadeloupe: Dr. Colardeau reported it as rather common from November to March in coffee plantations.

$$
\begin{gathered}
\text { Seiurus aurocapillus (Linnaeus) } \\
\text { OVEN-BIRD }
\end{gathered}
$$

Guadeloupe: Recorded by Bond.

Les Saintes: Recorded by Bond.

Seiurus noveboracensis noveboracensis (Gmelin) NORTHERN WATER-TRUSH

Guadeloupe: Ober obtained a female in mangroves bordering the Rivière Salée near Pointe-á Pitre. The Field Museum has 2 males from Guadeloupe, collected by Winch on September 18 and 28, 1890.

\section{Witsonia canadensis (Linnaeus) \\ CANADIAN WARBLER}

Guadeloupe: Reported by Dr. Colardeau.

$$
\begin{gathered}
\text { Setophaga ruticilla (Linnaeus) } \\
\text { AMERICAN-REDSTART } \\
\text { Petit Dufeu }
\end{gathered}
$$

Guadeloupe: Ober obtained an adult male, an immature male, and a female in September. These and three specimens obtained by Guesde are in the U.S. National Museum. The Field Museum has 2 specimens from Guadeloupe.

Marie Galante: Richardson obtained two in 1886.

$$
\begin{gathered}
\text { Holoquiscalus Tugubris guadeloupensis (Lawrence) } \\
\text { GUADELOUPE GRACKLE } \\
\text { Merle; Bout de Petun }
\end{gathered}
$$

Guadeloupe: On Guadeloupe proper we found it decidedly rare except on the westcoast from Vieux Habitants to Malendure, and in the northeastern region around La Boucan, Lamentin and Bonne Mere, where it was common. Elsewhere a very few were seen at 
Basse-terre, Goyave, Capesterre, and Petit Bourg. On Grand Terre it was much more common and generally distributed.

Seven adult males, three females, and one immature male were collected at Goyave, Malendure, La Boucan, Port-Louis (Grande Terre), Vieux-Bourg (Grande Terre) and Le Moule (Grande Terre).

Eleven stomachs contained Anotis lizards 42 per cent; land snails (mainly Helicina fascita) 41.5 per cent; cane weevils, Diaprepes spengleri, (20 in one stomach, and about an equal number in another), 12.8 per cent; rotten sugar cane borer weevils, Metamasius hemipterus (large number of individuals) 7.8 per cent; unidentified weevils 7.8 per cent; other Coleoptera 14 per cent; Locustid eggs 1.8 Basse-terre, Goyave, Capesterre, and Petit Bourg. On Grand Terre 7.4 per cent; other fruits 7.4 per cent; roots 3.3 per cent.

Marie Galante: Richardson obtained specimens in 1886. On July 17, 1937 we watched the birds congregating to roost in trees at the edge of the town of Grand Bourg in the evening. The next day we found the species common at Trois Islets, and collected a male.

\section{Tanagra flavifrons flavifrons (Sparrmann)}

\section{GREEN EUPHONIA}

Perrouche; Perrique de Matouba

Guadeloupe: Known only from high mountain forests. We found it only on the Soufrière, where it was rather common on June 29, 1937, and we collected a pair. The male had the iris dark grayish brown; upper mandible black; lower mandible grayish blue tipped with black; legs and feet slate gray, claws dusky, soles dull yellow. Both had eaten the customary mistletoe berries.

\section{Saltator albicollis guadeloupensis Lafresnaye GUADELOUPE SALTATOR \\ Gros-Bec}

Guadeloupe: We found it mostly in second growth thickets, where it could hardly be called rare. Regions in which it was observed were Dolé (female collected June 17, 1937); hills behind Goyave (male collected July 2); Sainte Marie (2 females collected June 24 and June 30); Sainte Rose, and Vieux-Bourg, Grande Terre (unsexed bird collected July 13). On June 24, 1937 near Sainte Marie a nest was found 20 feet from the ground in a densely foliaged tree. It was a cup-shaped, loosely constructed affair of roots and small twigs, 
and contained young nearly ready to leave the nest. All five stomachs contained both large weevils and fruits, a total of 26 per cent of weevils and 74 per cent of fruits (among which Solanaceous fruits formed 16 per cent).

\section{Tiaris bicolor omissa Jardine CARIB GRASSQUIT \\ Mangeur d'herbes; Cici-zèbe}

Guadeloupe: Common everywhere in open and brushy country in the lowlands; not found in the deep woods. Four adult males, one adult female, and two immature males were collected at Dolé, Fond Cabe, Bananier, La Boucan, and Port-Louis (Grande Terre). The seven stomachs contained small seeds, plus sand for grinding purposes.

Les Saintes: Common on Terre-de-Bas, and observed on Terrede-Haut. An adult male was collected on the former and a semiadult male on the latter on July 5, 1937. Both stomachs contained small seeds and sand. Not previously recorded.

Désirade: Collected by Richardson in 1886. On July 9, 1937 we found it common both in the lowlands and on the plateau, and collected an adult male, the stomach of which contained small seeds and sand.

Marie Galante: Collected by Richardson in 1886 . We found it common, and collected an adult male at Trois Islets on July 18, 1937. Its stomach contained the usual seeds and sand.

\section{- Loxigilla noctis dominicana (Ridgway)} DOMINICAN BULLFINCH

Père Noir (male); Gross-Bec (female).

Guadeloupe: Common and generally distributed, from the high mountain forests to the coastal swamps. This and the honey creeper are unquestionably the two commonest and most widely distributed birds on the island. Twelve specimens were collected, consisting of 5 adult males, 6 females, and 1 immature male, obtained on the Soufrière, and at Dolé, Trois Rivieres, Bananier, hills behind Goyave, and Vieux-Bourg (Grande Terre).

The twelve stomachs contained weevils 30.8 per cent, fruits 54.6 per cent, seeds 14.6 per cent, and many stomachs contained sand in addition. 
Les Saintes: Common on Terre-de-Bas, but not found on Terrede-Haut. A pair was collected on the former island on July 5, 1937. The male measures, wing 72.5 , tail 51.3 , culmen from base 17.2 , and tarsus 20.5 millimeters, and the female, wing 64.8 , tail 54.4, and tarsus 19.6 millimeters. One stomach contained berries and sand. Not previously recorded.

Marie Galante: Obtained by Richardson in 1886. On July 18, 1937 we observed two at Trois Islets, and found it fairly common in higher country back of Saint Louis, where we collected two adult males. These measure, wing 72.3-72.7 (72.5) ; tail 51.7-51.8 (51.75); culmen from base 15-16.7 (15.85) ; tarsus 20.3-21.2 (20.75) millimeters. Their stomachs contained weevils 32.5 per cent and seeds 67.5 per cent.

\section{Loxigilla noctis desiradensis Danforth DÉSIRADE BULLFINCH}

Père Noir; Gros-Bec

Désirade: Richardson collected three males on March 7, 8 and 11, 1886, and two females on March 11 and 13, 1886, and Bond a female on January 20, 1930. With all this material available for study, I described this form with one of Richardson's males in the Field Museum as the type (Journ. Agr. Univ. P. R., 21, 1937, p. 229) before our visit to Désirade. We had hoped to obtain a fair series there, but on the day of our visit (July 9, 1937), despite much diligent search, we were able to locate but one bird. That was an adult male, which was promptly collected, on the side of the mountain. Its iris was very dark brown; upper mandible black, lower dark horn color, more or less tinged with dusky in parts, and the posterior lateral parts were black; legs and feet slate gray, claws dusky, soles tinged with dull yellow. It measured, wing 68, tail 51.6, culmen from base 15.3, and tarsus 20 millimeters, thus agreeing well in size with other examples of this form. Its stomach contained small seeds and sand. 